\title{
Filed Comparative Investigation of Loading Test on Micro-Piles Installed with Different Technique - (Case Study)
}

\author{
M. N. Elsiragy
}

\begin{abstract}
Foundation can be subjected to additional load and constructed in soft soils; therefore, the settlement or foundation tilting is achieved. The most beneficial method to control the settlement and foundation tilting are to be used Micro-piles which have been considered is an effective and easy to reinforce the existing foundation, it also successfully adopted in many ground improvement techniques to safeguard structure from collapse. The paper aims to study the behavior of full-scale micro piles under compression in the filed with length of $20 \mathrm{~m}$ as end bearing with diameter of $88.9 \mathrm{~mm}$. This study is focused on the observing the behavior of three micro-piles installed with different technique. The first is normal one without injection as pipe piles MP1, the second is pipe pile with grouted bulb MP2 only under the toe of micro-piles and inside grouting. The last one or third micro-pile MP3 is pipe pile with fully injection for both toe and around the pile length. Three loading tests in the field are carried out to show the load settlement response under axial compression and horizontal load to get the ultimate micropile capacity. The results showed that the fully injected micropiles with grouting have a higher ultimate load capacity and minor settlement compared with other two cases. The ultimate load capacities for fully grouted micro-piles and only with grouted bulb are found to be 13 and 8 times of ultimate capacity of pipe micro-piles without grouted bulb at the toe respectively. Also, it is found that the ultimate horizontal load capacity of $\mathrm{Mp3}$ is found to be 27 ton while it is recorded as 3 and 4 ton for MP1 and MP3 respectively at horizontal displacement of 0.2 micro-pile diameter.
\end{abstract}

Index Terms - Field Load Test, Vertical and horizontal capacity, Micro Piles.

\section{INTRODUCTION}

In current years, the use of micro-piles has grown to be more and more extensive all over the world because of it is considered as easier installation for existing foundation with acceptable rates of daily creation and their extensive range of ground improvement applications. The use of micro-piles to reinforce foundations dates used since the 1950s post-war period and the rebuilding of cities in Italy [1].

There are many applications of adopting micro-piles in the field of ground improvement technology especially for reinforcing existing structure [2] and [3]. It also can be used for underpinning of Highway Bridge [4].

The micro-piles can be also used to stabilize slopes and increase the shear strength for control slope deformation [5] and [6]. Micro-piles are also considered as an excellent solution for seismic retrofitting of foundation due to their obtained frictional resistance structural grouting around piles and surrounding soils. The existence of such pressure grouting within the micro-piles can significantly provide improved load transfer system. It let the adjacent soil strength to be completely mobilized to increase the axial load capacity [7], [8]. The performance of any drilled micro-pile is greatly affected by the construction technique used to put in the pile into the soil and by the grouting procedure. Drilled micropiles are divided into category from $A$ to $D$, primarily on the origin of grouting type and pressure [9]. There is verity of researcher has been studied the model test behaviour of micro-piles in small scale technique. The tested micro piles to reinforce model raft for various situation, for example soil type, pile depth, and inclination angle are investigated in the laboratory [10], [11] the experimental results showed that if the micro-pile depth is adequately longer than the depth of foundation failure surface, the micro-piles will resist the ground deformation and extend the failure zone. On the other way filed analysis of micro-piles technology for ground improvement techniques has been done [12], [13]. Reference [12] provided a filed study to investigate the transferring load mechanism of single micro-piles in clay stratum. Although the above-mentioned research has contributed to the understanding of the behavior of single, [14] studied the load tests on micro-piles using full-scale field investigation. The filed results indicated that a new successful method to use embedded vibrating wire gauges is acceptable and recommended to be used due to the mobilization of negative skin friction around the pile shaft length, perhaps due to the great grouted volumes. The technique of micro-piles can also be used to reinforce foundation on expansive soils in large scale filed study [15]

Reference [16] investigated the field results a number of 260 hollow-bar micro-piles used to strengthening two bridges in New Jersey, which installed in submerged sand and in stiff silty clay. The micro-piles used in this research in the form of hollowbar micro-piles installed by pressure grouting, type B. The installation of such micro-piles achieved remarkable unit bond capacity in surrounding soils.

The lateral behavior of grouted micro-piles installed in marine soft clay is investigated by [17]. This research focused on the analysis of induced equivalent diameter of grouted micro-piles. The test consequences showed that, the lateral bearing capacity of the grouted micro-pile was enhanced by as much as 3,75 times of a non-grouted micro-pile. The pragmatic equivalent diameter was found to be about 1,5 
times the diameter of used pipe. This finding is helped, in predicting lateral load-deformation responses of the grouted micro-pile. In this research the full-scale loading tests for three types of micro-piles are carried out in the field to determine the filed load capacity. Afterward, the application of using such technique for strengthening existing raft foundation can be successfully used in a wide range. This technique is considered to be significant in resisting vertical and lateral capacity that can be investigated and confirmed in the current research. Therefore, in the paper there is discussed the large scale filed testing on three types of tested micropiles to show the optimum type to be used in solving geotechnical problems of existing foundations.

The first micro-pile is normal one without injection as pipe piles, the second is pipe pile with grouted bulb only under the toe of micro-piles and inside grouting. The last one or third micro-pile is pipe pile with fully injection for both toe and around the pile length. The behaviour of mentioned micropiles under both vertical and tension has been investigated with details to confirm the effectiveness of such technology.

\section{TESTED SITES AND SOIL CHARACTERIZATION}

The site under investigation is located in the Kafr ElSheikh Governorate, in Motorbus city. The soil sampling is carried out to show the nature of subsoil there, so the boring is extended to depth of $30 \mathrm{~m}$. Table I shows the soil profile related to the ground investigation carried out at the site. The subsoil was composed of a layer file to level $-3,00$ below the ground surface, followed by a stiff brown clay extended to level $-9.00 \mathrm{~m}$. Below this layer a dark gray peat layer with thickness of $1 \mathrm{~m}$ underneath gray soft silty clay with trace of sand pocket until level of $-18.00 \mathrm{~m}$. Finally, gray fine to medium sand is found to be at the end of borehole $-30.00 \mathrm{~m}$. a series of main laboratory tests were done to obtain the main geotechnical properties as illustrated in Table II. Physical properties of peat of peat layer which causes a failure to foundation in the form of additional settlement and tilting are mainly include decomposition degree, specific gravity, and bulk density. The main characteristics are shown in Table II. The main geotechnical properties of bearing sand layer were determined in the laboratory. The maximum dry density and minimum dry density are found to be $1.86,161 \mathrm{kN} / \mathrm{m}^{3}$, respectively. The angle of internal friction corresponding to maximum dry density is $43^{\circ}$.

TABLE II: MAIN CHARACTERISTICS OF PEAT TESTED IN THIS RESEARCH

\begin{tabular}{cc}
\hline \hline Property & \\
\hline Decomposition degree & Highly decomposed peat is higher \\
Unit weight/ Bulk density & than $40 \%$. \\
$\mathrm{kN} / \mathrm{m}^{3}$ & 9.81 \\
Specific gravity Gs & 1.48 \\
Organic content & 76 \\
\hline \hline
\end{tabular}

\section{INSTALLATION OF MICRO-PILES}

In the site, hydraulic, vibratory drilling rig that has a coring bit $150 \mathrm{~mm}$ in diameter was adopted for constriction the holes. Jets of water produced slurry from the soil during the drilling process, to preserve the stability of the hole sides. When the drill reached the predetermined depth, water was inserted into the hole to remove the slurry, until the water seems clean.

The used machine for such installation technique is shown in Fig. 1.
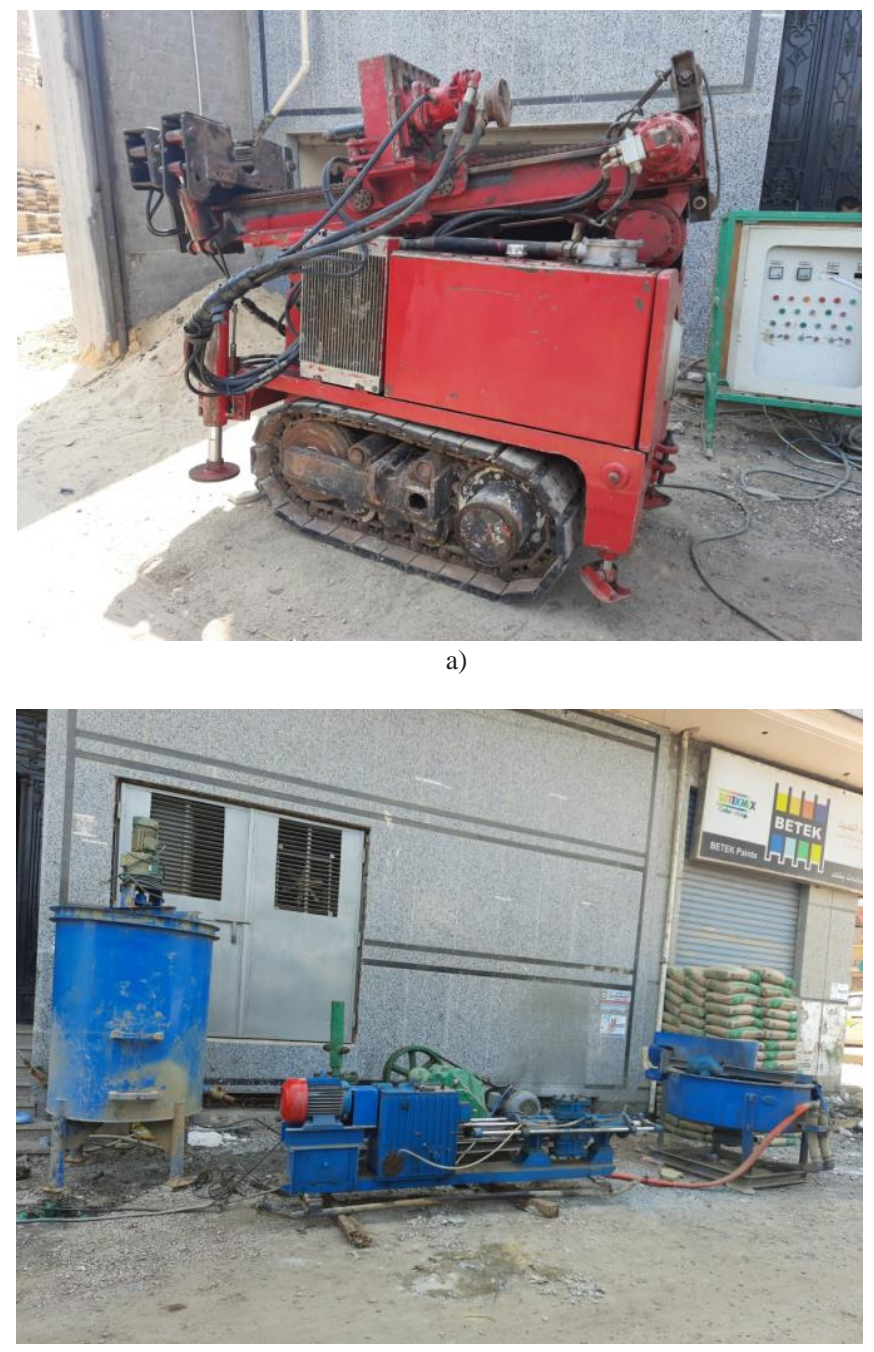

b)

Fig. 1. Installation Techniques:

a) installation machine for micro-piles drill rigs in the site; (b) pump station for grouting.

TABLE I: THE GEOTECHNICAL PROPERTIES OF THE SITES UNDER INVESTIGATION

\begin{tabular}{|c|c|c|c|c|c|c|c|c|c|c|c|c|}
\hline $\begin{array}{l}\text { Depth, } \\
\text { m }\end{array}$ & Soil stratification & Sand $\%$ & Clay\% & Silt $\%$ & $\mathrm{Wc} \%$ & L.L & PL & PI & $\begin{array}{l}\text { Cohesion } \\
\mathrm{C} \mathrm{kN} / \mathrm{m}^{2}\end{array}$ & $\mathrm{Cc}$ & $\phi$ & $\begin{array}{c}\text { Bulk } \\
\text { density } \\
\mathrm{kN} / \mathrm{m}^{2}\end{array}$ \\
\hline $0-3$ & Fill & \multicolumn{7}{|c|}{ NA } & & & & 16 \\
\hline $3-9$ & Brown stiff clay & 0 & 95 & 5 & 22 & 48 & 25 & 23 & 70 & 0.14 & - & 176 \\
\hline $9-10$ & Dark gray peat & 0 & 20 & 80 & 450 & 76 & 47 & 29 & 15 & 0.46 & 12 & 9.81 \\
\hline $10-18$ & Soft silty clay/sand pocket & 8 & 22 & 70 & 33 & 52 & 38 & 12 & 12 & 0.39 & 16 & 1.70 \\
\hline $18-30$ & Gary fine to medium sand & 96 & 0 & 4 & 18 & - & - & - & 0 & - & 38 & 1.80 \\
\hline
\end{tabular}


In the field, the steel pipe for micro-pile $20 \mathrm{~m}$ depth, with inner and outer diameter of $76 \mathrm{~mm}, 88.9 \mathrm{~mm}$ respectively, with yield strength of $550 \mathrm{MPa}$. According to type of grouting technique in the FHWA execution manual, case 1 and type B [18], micro-piles used classified as type B. The compressive strength of the grout used for the micro-piles was $35 \mathrm{MPa}$, and its corresponding tensile strength was 5.5 MPa. The hole was filled with cement grout from the bottom of the hole by applying pressures of $0.25-0.5 \mathrm{MPa}$, until the cement overflowed at the surface. The grout characteristics adopted in the field was neat cement grouts with water/cement ratios of 0.40 to 0.50 . Potable water used to reduce corrosion potential. Type I/II cement (FHWA, 2005), in bag or bulk form. Also, additives to improve pump-ability in special cases. The compressive strengths of 28 to $35 \mathrm{MPa}$. The nominal length of all micro-piles installed in the site are $20 \mathrm{~m}$. Grout was submitted from a complete-mix supplier, it pumped from a tank mounted concrete pump through an under head swivel into the tube as the drill rig (Fig. 1 a) withdrew the casing to the plan tip of casing elevation.

\section{MicRo-PILES VERTICAL LOAD TEST}

Load tests were done according to specifications presented by [19] and [20]. The micro-piles were installed in the site near the building in a free area permitted to carry out the field test. Three micro-piles cases have been investigated (case 1, type B) that installed using drill rigs as illustrated in Fig. 2. The first one normal pipe pile without grouting as a reference which is a normal steel tube with open end. The second is micro-pile with only grouted bulb at the toe to form the bond length. The last one is fully grouted known micro-pile with equivalent measured diameter around $19.5 \mathrm{~cm}$. The three types were investigated and tested under compression and lateral loads therefore tests are carried out in compression and horizontal loads for time of installation of grout 28days.

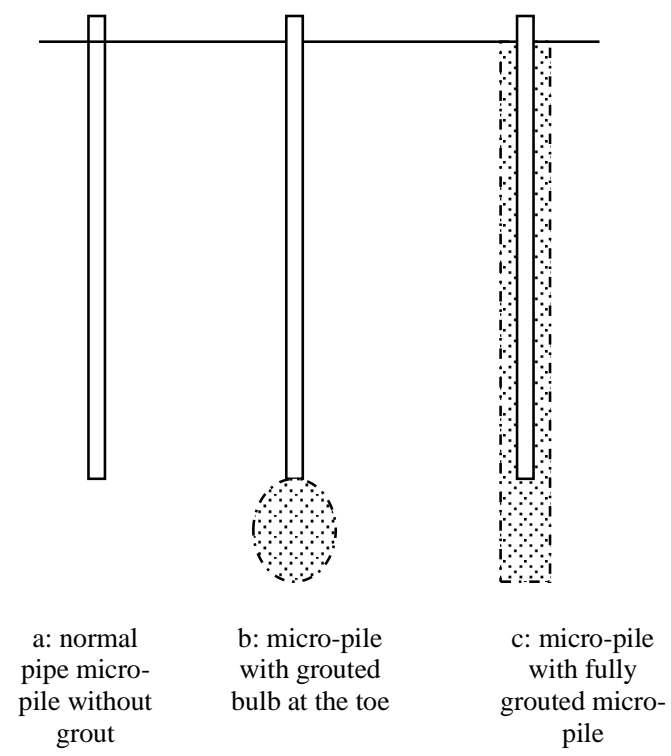

Fig. 2. General lay out of three tested micro-piles in the field.

The compression load was exerted by means of a hydraulic jack (capacity 150 ton) to the steel tubular reinforcement. Whereas the vertical settlement of the tested micro-piles head is measured by three dial gauges according to [19]. The loading technique consisted in the application of load increments equivalent to about $1 / 8$ of the micro-pile ultimate load $\mathrm{Q}_{\mathrm{u}}$, predictable by rough preface computations as stated by [21].

\section{FIELD RESULTS AND DisCUSSIONS}

\section{A. Definition Failure Compression Load}

There are many "analyses" of failure criteria that are mentioned for different micro-pile types [22], [23]. A number of the most commonly used failure criteria for determining the failure load for micro-piles. These methods can be divided into two main approaches: the first based on settlement limitation to get the failure criteria and the second is failure criteria with graphical construction. These mentioned methods related to pile diameter to get the failure load as a function on settlement limitations.

Reference [23] offset limit criterion Load corresponding to total settlement at the pile head $=$ PL/AE $+\mathrm{d} / 120+4(\mathrm{~mm})$. While Reference [23] suggested that the failure is defined the load corresponding to total displacement $=5 \% \mathrm{~d}$. Moreover, the micro-piles failure methods can be explained by extrapolation method that based on curve of load settlement behavior for tested micro-piles. According to Reference [24], the load displacement curve (Q-s) is considered to be a hyperbolic one. Since such, after some initial spread points at the beginning of the load application, a hyperbolic behavior a hyperbolic behavior is noticed which is shown in (1). Equation (2) provides the plunging failure according to Chin's method.

$\mathrm{s} / \mathrm{Q}=\mathrm{a} \mathrm{s}+\mathrm{b}$

$\mathrm{Qult}_{\mathrm{u}}=1 / \mathrm{a}$

where $\mathrm{s}$ is the recorded settlement for each load, Q is the applied load, "a" is the slope of the directly line formed on the plot of s/Q versus s, and " $b$ " is the y-intercept of the same line [24] Consequently, based on the above described methods, the ultimate load capacity of each tested micro-piles were determined by such described methods and the average ultimate compression load is determined in the help of Fig. 3 to 4 .

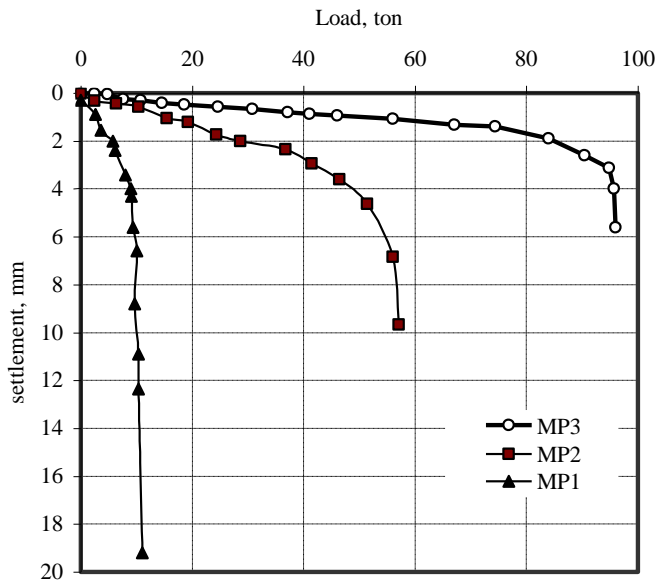

Fig. 3: Load settlement curves for tested micro-piles in the field. 

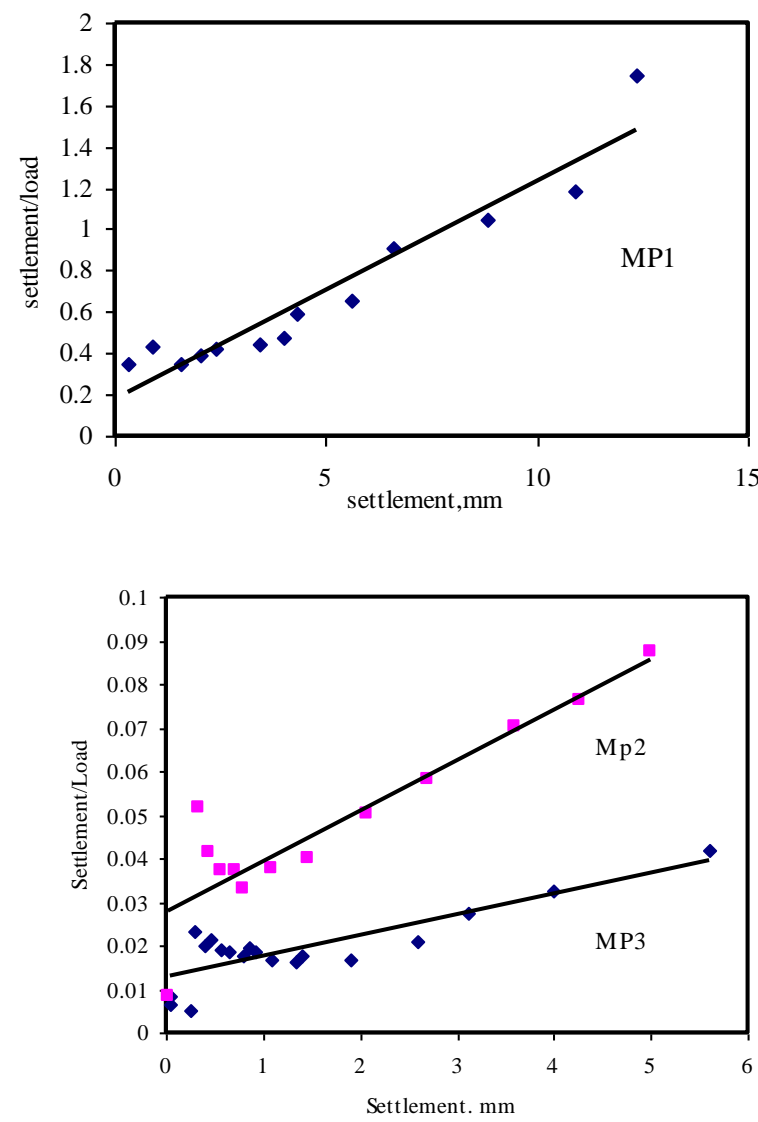

Fig. 4. Settlement load ratio versus settlement for micro-piles under compression: a) Micro-pile Mp, b) Micro-pile MP2 and Mp3.

\section{B. Load Settlement Response for Vertical Load}

Fig. 3 presents load-settlement responses of all three tested micro-piles in the field after 28 days of grouting process. The first loaded micro-piles without grouting as a steel pipe pile, named MP1 is provided for rough comparison with other two types. The micro-pile with grouted bulb at the toe, MP2 and the fully grouted normal micro-pile MP3 with equivalent diameter of $19.5 \mathrm{~cm}$ as measured in the field is mentioned in Fig. 3 and 4.

It can be seen that the pip pile MP1 has a least load capacity with higher settlement, because of this type of micro-pile has a smooth surface area and lesser end bearing area. Therefore, such micro-pile has minimum bearing at the toe and neglected friction resistance around its length. The settlement is reached to $20 \mathrm{~mm}$ corresponding to compression load of 7.15 ton.

While for other loaded micro-piles MP2 and MP3, the deformation responses are marked by a distinctive progressive hardening behaviour with remarkable increase of compression load with lesser settlement at early stage of loading until reaching to yield point. [24]

The behaviour of micro-pile MP2 with grouted bulb at the toe, shows a gradual yielding with the induced a relatively small displacement that increases rapidly at a threshold load corresponding to full end bearing without any side friction around the shaft. The compression load is found to be 57.38 ton due only base resistance. Whereas for MP3 the response of such micro-pile with fully grouted along the pile length, is described by a highly nonlinear load settlement curve. Where the large settlement is taking place the mobilization of side friction around the pile perimeter and base resistance of end bearing. The compression load test on micro-pile MP3 was interrupted at a load of 93.5 ton. This improvement on the load response is backed to the development of combined effect of base resistance and mobilization of side friction as a result the load capacity of micro-pile is distinctly increased compared with other two cases (MP1 and MP2).

In geotechnical engineering application, it is normally assumed that small-diameter bored piles transport their load to the soil through grout/soil shaft friction without any major donation from the pile end bearing base. This is due to numerous factors, for example the installation method and grouting method, the larger side area relative to the small base area and the certainty of a significant deformation or settlement of the base in order to fully activated the end bearing capacity at the base [5], [14], [25]. According to back-analysis for the curve of field tests of micro-piles and assuming a maximum displacement of $2 \mathrm{~mm}$, (Fig. 3) to fully mobilize the shaft friction. The net or total load-settlement curve of micro-pile MP3 showed that the effectiveness of both base resistance and development of side friction. It noticed that the base settlement frequently not being great enough to fully mobilize the whole base resistance. Considering the rigid response of the dense soil below the micro-pile grouted zone at the bases, which leads to good resistance and the load capacity is increased. As well as considering a combined introduction of shaft and base resistance is developed therefore the micro-pile response is well improved. Regarding above analysis it can be concluded that for normal pile or pipe micro-pile MP1, the friction resistance is neglected. Therefore, base resistance is rapidly induced one the micro-pile is loaded. It can be observed that at the settlement of $1.5 \mathrm{~mm}$ the base failure or end bearing failure is gradually starting to development due to concentration offload at smaller bearing area in sand at the base. The plunging point for yielding is achieved at settlement of $2.2 \mathrm{~mm}$. Whereas, for MP2 end bearing case due to grouted bulb produced at the base which has a diameter (Dg of 4 to 6 times of pile diameter (D), which is considered for the tested micro-pile around $55 \mathrm{~cm}$ as stated by [26] It can be made a sphercaical block of soil grout embedded in sand layer and the failure or yielding is gradually obtained at settlement ratio s/Dg 0f 0.07 (Fig. 3). Over the range of s/Dg $>0.07$ the progressive shear failure is obtained. On the other hand, for fully grouted micro-pile with both grouted bulb and interface grout along the pile length, the combined effect of both mobilized friction and end bearing are clearly achieved. First the side resistance can be mobilized rapidly until s/Dg equal to 0.025 after that the mobilization of end bearing resistance is slowly occurred. When the base settlement become larger sufficiently the base resistance is considered in the existence of dense layer at the micro-pile toe with grout soil block/ grouted bulb. So, the micro-pile capacity is significantly increased. Finally, it can be concluded that, the behaviors obviously show that the micro-piles under compression (MP2 and MP3) have upper load compression capacities than the micro-piles without grouting, MP1. The load capacity of MP3 is found to be 13, 1.63 times of Mp1 and $\mathrm{Mp} 2$, respectively. This wide range is confirmed the gab due to existence of combined effect of side resistance and tip base resistance [12]. 


\section{LOAD DISPLACEMENT RESPONSE}

\section{A. Reason of Study}

This investigation's intent is to provide an insight of the mean factors essential to provide a safe horizontal load capacity when considering lateral loads from seismic loads and wind. Therefore, micro-piles under lateral loading tests were performed. Three tests have been carried out for MP1, MP2 and MP3 for the same site condition and micro-pile configuration that stated before. The results of the lateral load test are shown in the form of the load vs deflection curve (Fig. 5 ). In this part of study, the ultimate lateral capacity was taken as the load corresponding to the horizontal displacement of 0.2 micro-pile diameter on the load-deflection curves, [27]. The results illustrated that the increasing rate of horizontal deformation was reached at about $0.2-0.35$ micro-pile diameter. It can also be seen that the lateral micro-pile capacity of fully grouted micro-pile (MP3) have a higher value with lesser horizontal deformation compared with micro-pile (MP1 and MP2). The two micro-pile MP1 and MP2 which are considered as a pip pile with lesser diameter has least capacity for lateral resistance for soil condition of the site. It is found that the ultimate load capacity of MP3 is found to be 27 ton while it is recorded as 3 and 4 ton for MP1 and MP3, respectively. This again justified the effectiveness of such grout around the pipe pile to form the micro-pile with significant stiffness. It also noticed that the first two micropile with low stiffness MP1 and MP2, the variation in the test result are trivial. Also, the grouted bulb at the toe of MP2 insignificant, it has a considerable effect on the base bearing and does not add any value for improving the lateral response. Finally, the normal micro-pile MP3 exhibit an acceptable lateral capacity to resist lateral load for foundation.

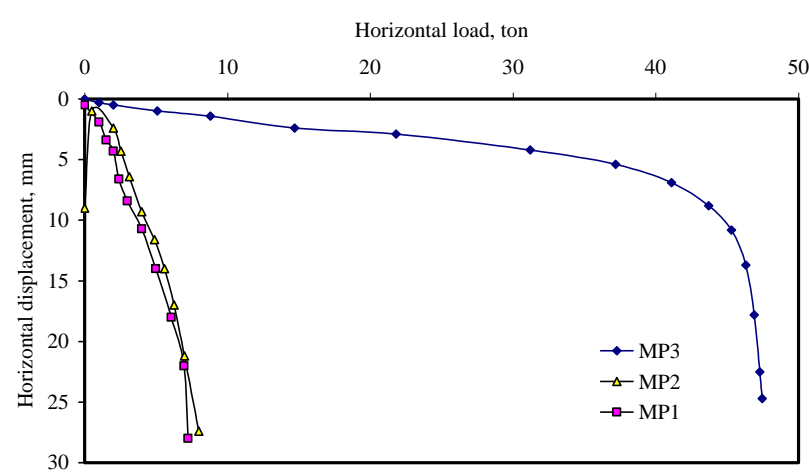

Fig. 5. Lateral displacement versus lateral load for different tested micro-piles in the field.

\section{CONCLUSION}

This field study has been carried out to confirm the effectiveness of micro-piles that installed in the field with different technique. The manuscript presented the large scale filed testing on three types of tested micro-piles to show the optimum type to be used in solving geotechnical problems of existing foundations.

The field results revealed that the axial capacity of pipe pile/hollow-bar micro-piles has a least vertical and lateral capacity compared with micro-piles with grouted bulb and fully grouted. The fully injected micro-piles with equivalent diameter of $20 \mathrm{~cm}$ have ultimate compression capacity 13 times of pipe pile with lesser settlement.

The improvement on the load response for MP3 is backed to the development of combined effect of base resistance and mobilization of side friction as a result the load capacity of micro-pile is distinctly increased compared with other two cases (MP1 and MP2).

The ultimate lateral capacity was taken as the load corresponding to the horizontal displacement of 0.2 micropile diameter on the load-deflection curves, [27].

It can also be seen that the lateral micro-pile capacity of fully grouted micro-pile (MP3) have a higher value with lesser horizontal deformation compared with micro-pile (MP1 and MP2). The two micro-pile MP1 and MP2 which are considered as a pip pile with lesser diameter has least capacity for lateral resistance for soil condition of the site. It is found that the ultimate load capacity of $\mathrm{Mp} 3$ is found to be 27 ton while it is recorded as 3 and 4 ton for MP1 and MP3, respectively. This again justified the effectiveness of such grout around the pipe pile to form the micro-pile with significant stiffness. It also noticed that the first two micropile with low stiffness MP1 and MP2, the variation in the test result are trivial.

This technique can be effective in strengthening the existing foundation and control the foundation settlement.

\section{REFERENCES}

[1] T. Armour, "Micropile Design and Construction Guidelines Implementation Manual" FHWA Federal Highway Administration Priority Technologies Program (PTP) Project 6, June, 2000.

[2] D.A Bruce, A. F. DiMillio, and E.G. Juran, "Micropiles: The state of Practice Part 2: Design of single micropiles and groups and networks of Micropiles" - Ground improvement, Thomas Telford, Vol.2, 1997.

[3] M. R. Ziaie and S.A. Naeini "Improvement of loose sandy soil deposits using micropiles". KSCE Journal of Civil Engineering 16(3): 334340.2012

[4] K. Larsson and D. Jog "Performance of micropiles used to underpin highway bridges". Journal of Performance of Constructed Facilities ASCE 28(3): 592-607.2014.

[5] I. Juran, A. Benslimane and D.A Bruce Slope stabilization by micropile reinforcement. Landslides 5: 1718-1726.1996.

[6] M. L. Lin, K.L. Wang, "Seismic slope behavior in a large-scale shaking table model test". Eng. Geol. 86 (2-3), 118-133.2006.

[7] C. Choi, S-D. Cho, J. Goo, J. Jeoung, K-H. Lee, J-H. Lee, "Foundation construction method of micro pile using pack used in the same, Korea Patent No.10-2008-0034653. 2008

[8] C. Choi, J-M. Goo, J-H Lee, and S-D Cho, "Development of New Micropiling Method Enhancing Frictional Resistance with Geotextile Pack", Proceeding of ISM 9th Workshop on Micropiles 2009, London, May 2009.

[9] FHWA, "Micro-pile Design and Construction. United States Department of Transportation", No. FHWA NHI-05-039, December, pp. 5-1-5-18.2005.

[10] T. Hwang, K. Kim, and H. Shin, "Effective installation of micropiles to enhance bearing capacity of micropiled raft. Soils and Foundations" ,Volume 57, Issue 1, Pages 36-49, , February 2017.

[11] W. R. Azzam, and A.M Basha, "Utilization of micro-piles for improving the sub-grade under the existing strip foundation: experimental and numerical study", Innovative Infrastructure Solutions (2018) 3:44, 2018.

[12] J. Han, and S.L. Ye, "A field study on the behavior of a foundation underpinned by micro-piles". Can. Geotech. J. 43 (1), 30-42,2006.

[13] Bellato, D'Agostini, Cola and Simonini "Behaviour of micropiles in heterogeneous coarse soils Proceedings of the Institution of Civil Engineers http://dx.doi.org/10.1680/jgeen.15.00069 pp:1-14, 2015.

[14] G. Russo, "Full-scale load tests on instrumented micropiles", Proceedings of the Institution of Civil Engineers - Geotechnical Engineering Volume 157 Issue 3, pp. 127-135, July 2004.

[15] O. Nusier, A.S. Alawneh, and R. Rabadi, “ Micropiles reinforcement for expansive soils: large-scale experimental investigation" 
Proceedings of the Institution of Civil Engineers - Ground Improvement 2007 11:2, 55-60, 2007.

[16] J.E. Gomez, C.J. Rodriguez, H.D. Robinson, J. Mikitka, and L/ Keough. "Hollow core bar micro-piles - installation, testing, and interpolation of design parameter of 260 micro-piles." In Proceedings of the 8th International Workshop on Micropiles, Toronto, Ont., 22-26 September 2007. [CD-ROM]

[17] L. Wen, G. Kong, Q. Li, and Z. Zhang, "Equivalent diameter of grouted micropile embedded in marine soft clay under lateral load" Proceedings of the Institution of Civil Engineers - Geotechnical Engineering 2020 173:1, 3-12, 2020.

[18] T. Armour, P. Groneck, J. Keeley, S. Sharma "Micropile Design and Construction Guidelines. Implementation Manual. Federal Highway Administration, FHWA-SA-97-070., 1997.

[19] ASTM (1994) - D1143-81 Standard Test Method for piles under static axial compressive load

[20] ASTM (1995) - D3689-90 Standard Test Method for individual piles under static axial tensile load.

[21] D. Bellato, S. D'Agostini, and P. Simonini, "Interpretation of failure load tests on micropiles in heterogeneous Alpine soils" Rivista Italiana di Geotecnica, 1. pp.1-16, 2013
[22] M.T Davisson, "High capacity piles. Proceedings, Lecture Series, Innovations in Foundation Construction", ASCE, Illinois Section, 52 pp, 1972.

[23] L. C. Reese, and M. W. O'Neill "Drilled Shaft, Student Workbook." Publication for FHWA-HI-88-042. FHWA, U.S. Department of Transportation, 1988.

[24] F.K. CHIN, "Estimation of the ultimate load of piles not carried to failure". Proc. 2nd Southeast Asian Conf. on Soil Engng., Singapore, pp. 81- 90, 1970

[25] P.J. Sabatini, B. Tanyu, T. Armour, P. Groneck and J. Keeley "Micropile Design and Construction - Reference Manual. Federal Highway Administration, Washington, DC, USA, FHWA-NHI-05039, 2005.

[26] Yueying Bian; Tara C. Hutchinson; Dan Wilson; Debra Laefer; and Scott Brandenberg "Experimental Investigation of Grouted Helical Piers for Use in Foundation Rehabilitation". Journal of Geotechnica and Geoenvironmental Engineering .Volume 134 Issue 9 - September 2008.

[27] B. Broms, "Lateral resistance of piles in cohesive soils," Soil Mechanics and Foundations Division, vol. 90, pp. 27-63, 1964. 